\title{
Intercomparison of Aerosol Optical Depth from Brewer Ozone spectrophotometers and CIMEL sunphotometers measurements
}

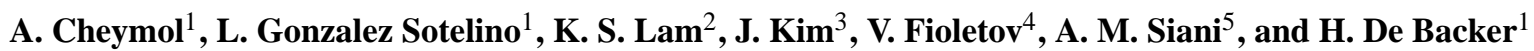 \\ ${ }^{1}$ Royal Meteorological Institute of Belgium, Dept. of Observations, Avenue Circulaire 3, 1180 Brussels, Belgium \\ ${ }^{2}$ Hong Kong Polytechnic University, Dept. of Civil and Structural Engineering, Hong Kong \\ ${ }^{3}$ Yonsei University, IEAA BK21 Program, Global Environment Laboratory, Department of Atmospheric Science, \\ Seoul, Korea \\ ${ }^{4}$ Environnement Canada, Experimental Studies Section, Science and Technology Branch, 4905 Dufferin Street, M3H 5T4, \\ Toronto, ON, Canada, \\ ${ }^{5}$ Department of Physics, University of Rome “La Sapienza”, P. le Aldo Moro, 200185 Rome, Italy
}

Received: 28 March 2008 - Published in Atmos. Chem. Phys. Discuss.: 17 June 2008

Revised: 8 December 2008 - Accepted: 17 December 2008 - Published: 29 January 2009

\begin{abstract}
The Langley plot method applied on the Brewer Ozone measurements can provide accurate Aerosol Optical Depth (AOD) in the UV-B. We present seven intercomparisons between AOD retrieved from Brewer Ozone measurements at $320 \mathrm{~nm}$ and AOD measured by CIMEL sunphotometer at $340 \mathrm{~nm}$ or $440 \mathrm{~nm}$ (shifted to $320 \mathrm{~nm}$ in using the Angström's law), which are stored in the international AERONET database. Only the intercomparisons between co-located instruments can be used to validate the Langley Plot Method applied to the Brewer measurements: in this case, all the correlation coefficients are above 0.82. If the instruments are not at the same site, the correlation between the AOD retrieved by both instruments is much lower. In applying the Angström's law the intercomparison is improved compared to previous study.
\end{abstract}

\section{Introduction}

The density of the aerosol particles is a key parameter in the radiative budget of the atmosphere. The direct aerosol effect in absorbing and scattering the solar radiation has, indeed, a major impact on the radiative budget (Roberts and Jones, 2004; Wild et al., 2005, 2007; See et al., 2006; Chou et al., 2006; Pfeifer et al., 2006; Mallet et al., 2005). Aerosol particles have also significant indirect effect as they play the role of the cloud condensation nuclei in the atmosphere (IPCC,

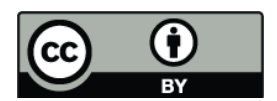

Correspondence to: A. Cheymol (ach@ibgebim.be)
2001). The retrieval of the aerosol parameters such as the Aerosol Optical Depth (AOD) is still an important challenge for the research community.

The Brewer network consists of about 200 spectrophotometers (http://www.io3.ca/), making measurements, in the UV-B radiation band. The retrieval of AOD from these instruments using the Langley Plot Method (LPM) represents complementary information to the AOD in the visible spectrum obtained with other instruments (de La Casinière et al., 2005). Even if such information is limited, this approach is still useful since it potentially makes possible to determine AOD for about 200 instruments: some of them have 1520 years long records. The method was developed and described in previous studies (Marenco et al., 1997; Carvhallo and Henriques, 2000; Gröbner et al., 2001; Cheymol and De Backer, 2003; Bais et al., 2004; Kazadzis et al.,2005). Validation studies have also already been done (Gröbner and Meleti 2004; Jaroslawski and Krzyscin, 2005; Savastiouk and Mc Elroy, 2005; Cheymol et al., 2006; Sellitto et al., 2006) to provide information on the accuracy of the AOD in the UV-B from Brewer instruments.

In this paper, compared to the other studies, the intercomparisons between AOD from Brewer spectrophotometers and CIMEL sunphotometers measurements are done in using the Angström's law on the AOD measured by the CIMEL sunphotometer. The wavelength effect on AOD is then removed. Moreover, the intercomparisons are made at seven locations with different meteorological conditions and different Brewer instruments. Therefore, the validation of the method is more extensive than when it is only performed at one location. 
Table 1. Contribution of the uncertainty on Calibration Factor $(\mathrm{CF})$ to the Error on the AOD for $320.1 \mathrm{~nm}$ at each site. $\mathrm{N}$ is the number of $\mathrm{CFs}$ used to calculate the mean $\mathrm{CF}$ and its $1 \sigma$.

\begin{tabular}{lccc}
\hline Site & Mean $\mathrm{CF} \pm 1 \sigma$ & Error on AOD due to CF & $\mathrm{N}$ \\
\hline Uccle & $17.83 \pm 0.21$ & 0.03 & 64 \\
Toronto & $17.30 \pm 0.15$ & $0.02(1984-1992)$ & 91 \\
& $18.36 \pm 0.12$ & $0.01(1992-2003)$ & 77 \\
& $18.46 \pm 0.13$ & $0.03(2003-2004)$ & 27 \\
& $18.34 \pm 0.11$ & $0.02(2005-2007)$ & 29 \\
El Arenosillo & $19.61 \pm 0.11$ & 0.01 & 353 \\
Norrköping & $18.92 \pm 0.09$ & 0.02 & 21 \\
Seoul & $18.47 \pm 0.09$ & 0.04 & 5 \\
Hong Kong & $18.11 \pm 0.34$ & 0.05 & 45 \\
Rome & $19.03 \pm 0.17$ & 0.02 & 50 \\
\hline
\end{tabular}

The method used to retrieve the AOD from Brewer Ozone measurements is briefly explained in section 2 . The validation of the AOD obtained in using LPM will be made in section 3 in comparing AOD from Brewer spectrophotometers and the CIMEL sunphotometers belonging to the AERONET database (http://aeronet.gsfc.nasa.gov/) at seven different stations.

\section{Method}

The LPM is used to retrieve the AOD from the Brewer spectrophotometer. The instruments are calibrated by using this linear regression method and then the Calibration Factor (CF) can be determined: the CFs for Uccle, El Arenosillo, Seoul, Norrköping and Rome are constant over the period considered here. For Toronto, as there were some technical changes in the Brewer's calibration, the CFs are levelled: they are constant from 1984 to February 1992, then they are shifted for the period March 1992 to December 2002, changed again from January 2003 to December 2004 and finally shifted again from January 2005 up to now. For Hong Kong, the CFs are interpolated over the whole period. The error due to the uncertainty on the CFs are shown in Table 1 for each Brewer and for $320.1 \mathrm{~nm}$. The error on AOD due to uncertainty on CF is, for most of the Brewers, below 0.03 except for the Brewers in Hong Kong and Seoul, where it is equal to 0.05 and 0.04 , respectively. Another contribution to this error is also coming from the uncertainty on ozone at $320 \mathrm{~nm}$, which is equal to 0.004 (Cheymol and De Backer, 2003).

The AOD are calculated only for cloudless days. To select these days, several tests are applied on the Brewer ozone measurements (Cheymol et al, 2006). To remove the stray light effect, which contaminated the AOD values (Cede et al., 2006; Arola and Koskela, 2004), a test on the airmass factor is added compared to previous studies (Cheymol and De Backer, 2003, Cheymol et al, 2006). Once the calibration of the Brewer spectrophotometer is determined with LPM, the AOD can be calculated for each individual Direct Sun (DS) measurement. Below, the list of the tests to select cloudless days on the DS radiation are summarised:

1. The individual DS data for which the airmass is above 3 are removed.

2. The ozone column and its standard deviation are computed on each group of five individual DS measurements for each wavelength. Data are accepted if the standard deviation is lower than $2.5 \mathrm{DU}$.

3. The range of zenith angles covered by valid DS observations for one day must be at least $20^{\circ}$.

4. The number of the individual DS data must be at least 50 per day (i.e 10 sequences of 5 observations).

5. The distance between each point and the Langley Plot regression line must be lower than 4 .

6. The daily mean absolute deviation of the distance between each point and the Langley Plot regression line must be lower than 0.055 .

For more details on the method used to calibrate the Brewer instrument, see Cheymol and De Backer (2003) and Marenco (2002)

\section{Intercomparisons between AOD from Brewer spec- trophotometer and CIMEL sunphotometer}

The automatic CIMEL observes the DS radiations and scans the sky at several wavelengths $(340,440,670,870$ and $1020 \mathrm{~nm}$ ) according to AERONET protocols, as part of this network (Holben et al., 1998).

During routine ozone observations, the Brewer spectrophotometer makes 5 individual DS ozone observations within $3 \mathrm{~min}$ at five wavelengths in the UV-B $(306.3 \mathrm{~nm}$, $310.1 \mathrm{~nm}, 313.5 \mathrm{~nm}, 316.7 \mathrm{~nm}$ and $320.1 \mathrm{~nm}$ ) with a Full Width Half Maximum (FWHM) of about $0.6 \mathrm{~nm}$. This intercomparison uses only the largest wavelength of the Brewer spectrophotometer at $320 \mathrm{~nm}$ as it is the closest to the wavelength of the CIMEL. This wavelength is selected between 340 and $440 \mathrm{~nm}$ (see Table 2) according to the CIMEL sites (http://aeronet.gsfc.nasa.gov). The sun tracking of the Brewer is regularly checked by visual inspection. The stability of the tracking system is claimed by Kipp and Zonen to be of the order of $0.2^{\circ}$. This should be a random error and should not cause any bias on the AOD measurements. For Brewer Mark II like at Uccle and Toronto, a stray light effect exists for wavelength below $313.5 \mathrm{~nm}$, which impacts the AODs (Arola and Koskela, 2004): nevertheless, the single Brewer instrument has a NiSO4 filter to cut off light from longer wavelengths and it has the best transmittance at 315$320 \mathrm{~nm}$. In this study, as only the $320.1 \mathrm{~nm}$ wavelength is 
Table 2. List of the sites (Uccle in Belgium, Toronto in Canada, El Arenosillo in Spain, Norrköping in Sweden, Seoul in Korea, Hong Kong in China and Rome in Italy), the instruments (B**** for the Brewer) and the distance between the instruments, the wavelength $\lambda$ (in boldface for Brewer) and the period of the data used.

\begin{tabular}{lccc}
\hline Site & \multicolumn{1}{c}{ Instruments } & $\lambda(\mathrm{nm})$ & Period used \\
\hline Uccle & co-located: B\#016 MkII, CIMEL & $320.1,340$ & $2006-2007$ \\
Toronto & co-located: B\#008 MkII, CIMEL & $320.1,340$ & $1996,2003-2007$ \\
Norrköping & co-located: B\#128 MkIII, CSEM & $320.1,368$ & 2004 \\
El Arenosillo & co-located: B\#150 MkIII, CIMEL & $320.1,440$ & $2000-2006$ \\
Seoul & 16 km far: B\#148 MkIV, CIMEL & $320.1,440$ & $2000-2001$ \\
Hong Kong & 12 km far: B\#115 MkIV, CIMEL & $320.1,340$ & $2005-2006$ \\
Rome & $15 \mathrm{~km}$ far: B\#067 MkIV, CIMEL & $320.1,440$ & $2002-2006$ \\
\hline
\end{tabular}

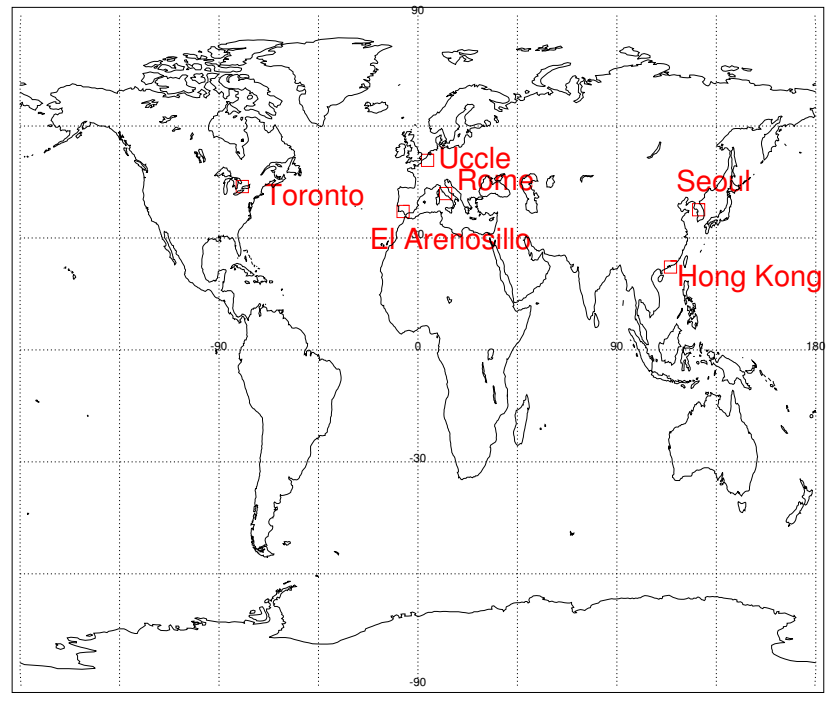

Fig. 1. The six stations used in this paper: Uccle in Belgium, Rome in Italy, El Arenosillo in Spain, Toronto in Canada, Seoul in Korea and Hong Kong in China.

considered, this effect is negligible on AOD. The range of the zenith angle for all the Brewer is between at the lowest $13.68^{\circ}$ (El Arenosillo) up to $71.10^{\circ}$ as all the AOD measurements for which the airmass is above 3 are removed (see Table 3). To remove the effect of the wavelength difference between the instruments, the Angström's law (Angström, 1964) is applied on the AOD measured by the CIMEL to shift it to $320 \mathrm{~nm}$. The Angström's coefficient $\alpha$ calculated from the CIMEL measurements is used. All the plots show the comparison between the AOD at $320 \mathrm{~nm}$ measured by the Brewer and the AOD from CIMEL at 340,368 or $440 \mathrm{~nm}$ shifted to $320 \mathrm{~nm}$

Figure 1 shows the location of the different stations used in this study. The common period of each intercomparison is listed in Table 2.
Table 3. Range of the zenith angle corresponding to AOD measurements for each Brewer stations.

\begin{tabular}{cc}
\hline Site & Range of zenith angle in ${ }^{\circ}$ \\
\hline Uccle & $28.44-71.09$ \\
Toronto & $20.34-71.08$ \\
Norrköping & $35.16-71.09$ \\
El Arenosillo & $13.68-71.09$ \\
Seoul & $52.70-70.59$ \\
Hong Kong & $41.21-70.93$ \\
Rome & $18.46-71.09$ \\
\hline
\end{tabular}

At Norrköping in Sweden, the AODs obtained from the Brewer ozone measurements at $320 \mathrm{~nm}$ have already been validated with AOD from a co-located sunphotometer (Cheymol et al., 2006) at $368 \mathrm{~nm}$. In this paper, the AOD at $368 \mathrm{~nm}$ are shifted to $320.1 \mathrm{~nm}$ to remove the wavelength's effect on AOD.

Quasi simultaneous AOD from the Brewer and the CIMEL are compared. We consider only measurements of both instruments with a maximum time difference of three minutes. The absolute linear regression is used: this method is more representative for the group of AOD than the least mean square linear regression, which is very sensitive to outliers. The error on the regression parameters has been estimated in using the bootstrap method with 10000 iterations. This error represents a $68.3 \%$ confidence limit and can be safely interpreted as $1 \sigma$ (Efron and Tibshirani, 1986).

\subsection{Co-located instruments}

\subsubsection{Uccle, Belgium}

Uccle is located near Brussels in Belgium $\left(50^{\circ} 48^{\prime} \mathrm{N}, 4^{\circ} 21^{\prime} \mathrm{E}\right.$, $100 \mathrm{~m}$ a.s.l.) in a residential area. It is strongly affected by pollution (BIM, 2004). Two Brewer instruments are situated on the roof of a building of the Royal Meteorological Institute of Belgium (RMIB) and are re-calibrated every 2-3 


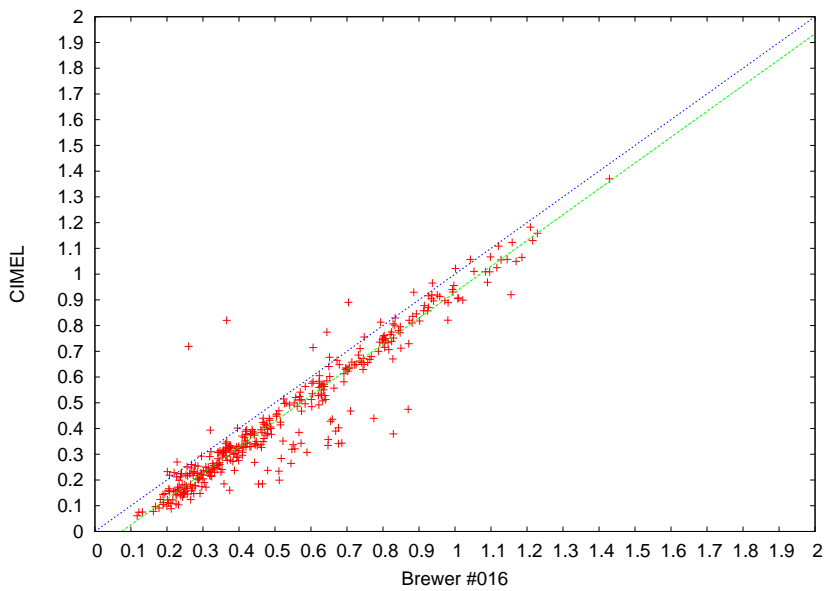

Fig. 2. 373 AODs from CIMEL at $340 \mathrm{~nm}$ shifted to $320 \mathrm{~nm}$ versus the AODs from Brewer \#016 at Uccle in Belgium since April 2006 to 2007 . The green and the blue lines represent the equation $f(x)=x$ and the absolute linear regression line for the data, respectively. The correlation coefficient, the slope and the intercept are $0.96,1.0041 \pm 0.0183,-0.0744 \pm-0.0122$, respectively.

years since 2001. The AOD from the single monochromator MKII \#016 will be used for this intercomparison with the colocated CIMEL belonging to the Belgian Institute for Space Aeronomy.

The single monochromator Brewer MARK II \#016 (SCI TEC, 1988) and the CIMEL sunphotometer (www.cimel.fr/ index_us.html) are $100 \mathrm{~m}$ far from each other. They are considered as co-located. The two instruments measure the direct solar intensity at $320 \mathrm{~nm}$ and at $340 \mathrm{~nm}$, respectively. The AODs at $340 \mathrm{~nm}$ from the CIMEL are shifted to $320 \mathrm{~nm}$ in using the Angström's coefficient $\alpha$ between 340 and $440 \mathrm{~nm}$ of the CIMEL. The CIMEL sunphotometer operated since July 2006. Since 1984, the Brewer spectrophotometer \#016, which is a single monochromator is routinely operated at Uccle to measure the total ozone column in the atmosphere from the DS ultraviolet radiation.

Figure 2 shows the scatter plot of the 373 AODs from Brewer \#016 and the CIMEL sunphotometer at Uccle since April 2006. There is a very good linear agreement between AODs from the two instruments: the correlation coefficient, the slope and the intercept of the regression line are 0.96, $1.0041 \pm 0.0183$ and $-0.0744 \pm 0.01225$, respectively. This bias of 0.07 , which is statistically significant, is not yet explained.

\subsubsection{Toronto, Canada}

The Brewer spectrophotometer \#008 is located at the top of the building in a big Canadian city $\left(43^{\circ} 78^{\prime} \mathrm{N}, 79^{\circ} 468^{\prime} \mathrm{W}\right)$. Its calibration is maintained by Environment Canada, who also keeps the World standard triad for Brewer observations (Fioletov et al., 2005). It is a Mark II spectrophotometer.

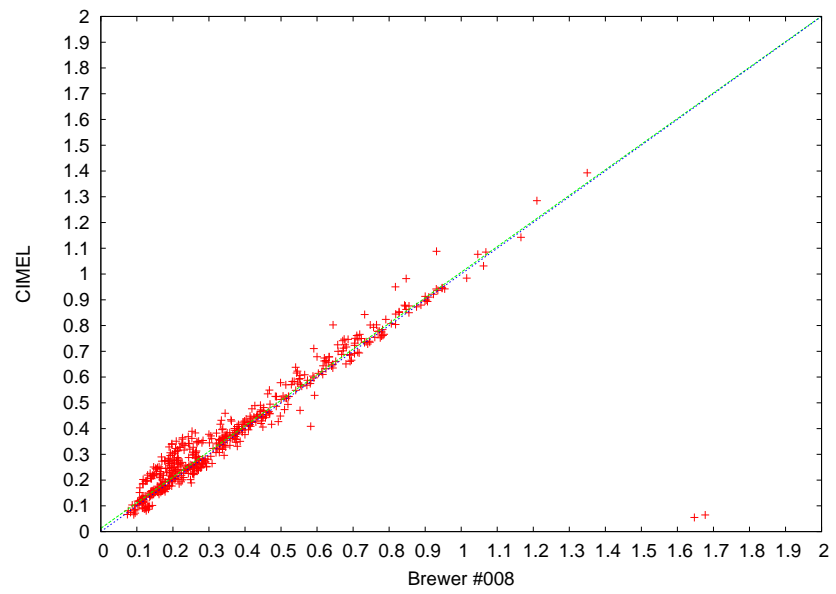

Fig. 3. 550 AODs from CIMEL at $340 \mathrm{~nm}$ shifted to $320 \mathrm{~nm}$ versus the AODs from Brewer \#008 at Toronto in Canada since 1996 to 2006. The green and the blue lines represent the equation $f(x)=x$ and the absolute linear regression line for the data, respectively. The correlation coefficient, the slope and the intercept are $0.90,0.9943 \pm 0.0188,0.0128 \pm 0.0060$, respectively. These parameters are clearly improved without considering the 2 outliers $(0.98$; $1.0000 \pm 0.0176 ; 0.0110 \pm 0.0056)$.

This instrument is a part of the Brewer triad and is calibrated on a regular basis at Mauna Loa, Hawaii. The site is moderately affected by pollution. It is located in an urban area near the intersection of two busy streets in the vicinity of a large park. The co-located CIMEL sunphotometer measures at $340 \mathrm{~nm}$. The AODs at $340 \mathrm{~nm}$ from the CIMEL are shifted to $320 \mathrm{~nm}$ in using the Angström's coefficient $\alpha$ between 340 and $440 \mathrm{~nm}$ of the CIMEL.

At Toronto, the single monochromator MARK II Brewer \#008 and the CIMEL sunphotometer are operated since 1984 and 1996, respectively. 550 quasi simultaneous AODs at $320 \mathrm{~nm}$ and $340 \mathrm{~nm}$ shifted to $320 \mathrm{~nm}$ are compared from the Brewer and the CIMEL, respectively on Fig. 3. The correlation coefficient is high, 0.90 . The slope and the intercept of the regression line are $0.9943 \pm 0.0188$ and $0.0128 \pm 0.0060$, respectively. As in Uccle, a very high correlation coefficient is also found at Toronto. Nevertheless, two points affect the results: in removing these two points (AOD above 1.6 on the $\mathrm{X}$ axis on Fig. 3), the correlation coefficient is improved $(0.98)$ with a slope and an intercept equal to $1.0000 \pm 0.0176$ and $0.0110 \pm 0.0056$, respectively.

\subsubsection{Norrköping, Sweden}

The Brewer \#128 and CSEM2000 sunphotometer are located near the city of Norrköping in Sweden $\left(58^{\circ} 35^{\prime} \mathrm{N}, 16^{\circ} 09^{\prime} \mathrm{E}\right)$. The surroundings within $1 \mathrm{~km}$ of its platform is a mixture of suburban low buildings, gardens, lawns, roads and trees. The horizon is free of obstacles above $5^{\circ}$. Brewer \#128 is a Mark III, which is regularly calibrated by comparison to a travelling reference Brewer. 


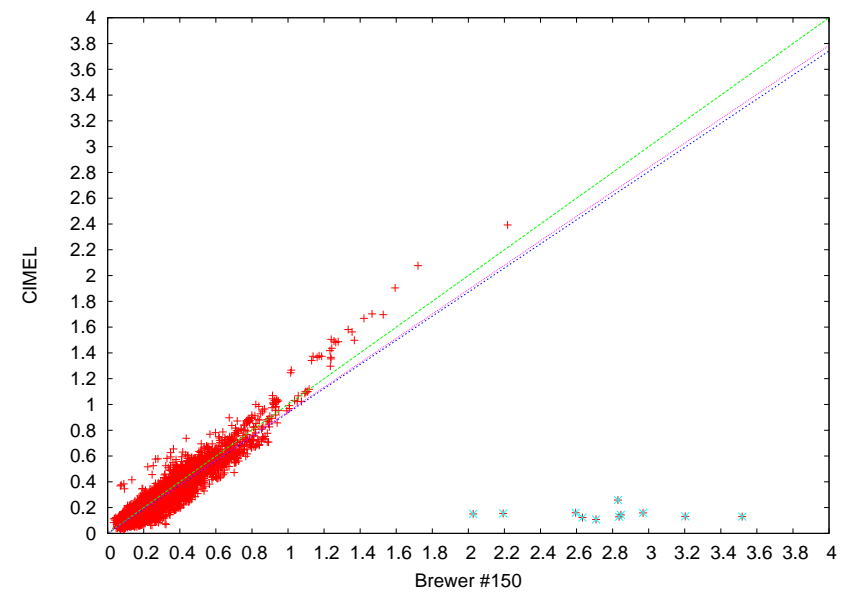

Fig. 4. 7386 AODs from CIMEL at $440 \mathrm{~nm}$ shifted to $320 \mathrm{~nm}$ versus the AODs from Brewer \#150 at El Arenosillo in Spain. The green and the blue lines represent the equation $f(x)=x$ and the $a b-$ solute linear regression line for the data, respectively. The red line represents the absolute linear regression without the 11 outliers (red points with light blue cross). The correlation coefficient, the slope and the intercept are $0.82,0.9356 \pm 0.0149,0.0001 \pm 0.0030$, respectively. These parameters are clearly improved without considering the 11 outliers $(0.95 ; 0.9467 \pm 0.0124 ;-0.0022 \pm 0.0027)$.

The sunphotometer CSEM2000 is located at the same platform on the roof of the Swedish Meteorological and Hydrological Institute (SMHI) in Norrköping. It measures the AODs at $368 \mathrm{~nm}$, which are shifted to $320 \mathrm{~nm}$ for the intercomparison with the Brewer. The AODs at $368 \mathrm{~nm}$ from the CSEM2000 are shifted to $320 \mathrm{~nm}$ in using the Angström's coefficient $\alpha$ between 368 and $778 \mathrm{~nm}$ of the CSEM2000. 1522 AODs are then compared. As it was mentioned in (Cheymol et al., 2006), without shifting the AOD, the slope of the fitting line was equal to 0.85 . In removing the effect of the wavelength, the slope becomes $1.0129 \pm 0.0097$ and the intercept $-0.0153 \pm 0.0024$ (compared to $0.02 \pm 0.0014$ ). The correlation coefficient is similar for the two intercomparisons.

\subsubsection{El Arenosillo, Spain}

The Brewer spectrophotometer \#150 and the CIMEL sunphotometer are operated since 2000 on the roof of INTA (Instituto Nacional de Tecnica Aeroespacial), which is in El Arenosillo located near Huelva $\left(37^{\circ} \mathrm{N}, 6^{\circ} 12^{\prime} \mathrm{W}, 17 \mathrm{~m}\right.$ a.s.l.) on the southwestern Spanish coast. El Arenosillo is surrounded by a pine tree forest and is located within Donana National Park, a protected coastal area.

The Brewer spectrophotometer \#150, which is a MARK III, routinely operates at El Arenosillo to provide ozone values and global UV irradiance since 1998.

The CIMEL sunphotometer and the MARK III Brewer spectrophotometer are co-located and measure the DS radiation at $440 \mathrm{~nm}$ and $320 \mathrm{~nm}$, respectively. The AODs at

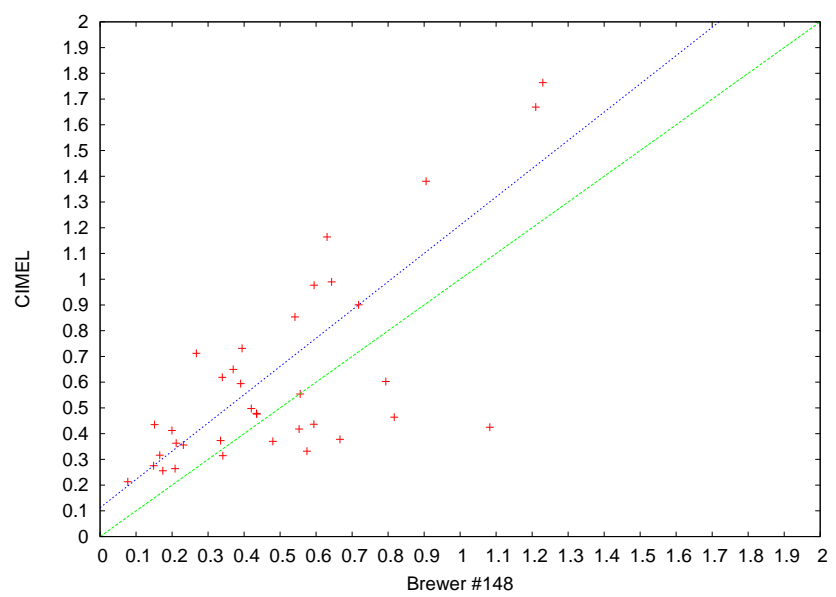

Fig. 5. 36 AODs from CIMEL at $440 \mathrm{~nm}$ shifted to $320 \mathrm{~nm}$ versus the AODs from Brewer \#148 at Seoul in Korea. The green and the blue lines represent the equation $f(x)=x$ and the absolute linear regression line for the data, respectively. The correlation coefficient, the slope and the intercept are $0.72,1.0979 \pm 0.8844$, $0.1122 \pm 0.1820$, respectively.

$440 \mathrm{~nm}$ from the CIMEL are shifted to $320 \mathrm{~nm}$ in using the $\alpha$ coefficient between 440 and $870 \mathrm{~nm}$ of the CIMEL. Figure 4 shows the scatter plot of the 7386 AODs from Brewer $\# 150$ and the CIMEL sunphotometer at El Arenosillo. It can be observed that there is a good linear agreement between AODs from the two instruments: the correlation coefficient, the slope and the intercept of the regression line are $0.82,0.9356 \pm 0.0149$ and $0.0001 \pm 0.003$, respectively. If we remove the 11 outliers (see the red points with blue cross on Fig. 4), the comparison is clearly improved: the correlation coefficient, the slope and the intercept of the regression line are $0.95,0.9467 \pm 0.0124$ and $-0.0022 \pm 0.0027$, respectively. No explanation for these 11 points is found yet. For more details on selection of outliers, see Sect. 4 . The calibration of the CIMEL could be one of the reason to explain the discrepancy of the slope of the regression line compared to the one at the three other sites (Uccle, Toronto and Norrköping) here the slope is very close to 1 (Toledano, 2005). The Angström's coefficient $\alpha$ used at El Arenosillo is further from $320 \mathrm{~nm}$ than the one used at the three other sites and this could be another explanation. Further investigation is needed to understand where the outliers are coming from and why the slope is not so good at El Arenosillo compared to Uccle, Toronto and Norrköping.

\subsection{Brewer and CIMEL at different sites}

\subsubsection{Seoul, Korea}

Seoul is a big city in Asia $\left(37^{\circ} 34^{\prime} \mathrm{N}, 126^{\circ} 58^{\prime} \mathrm{E}\right)$, which is mostly influenced by pollution from industry in the surroundings. The Brewer Mark IV spectrophotometer \#148 and the 


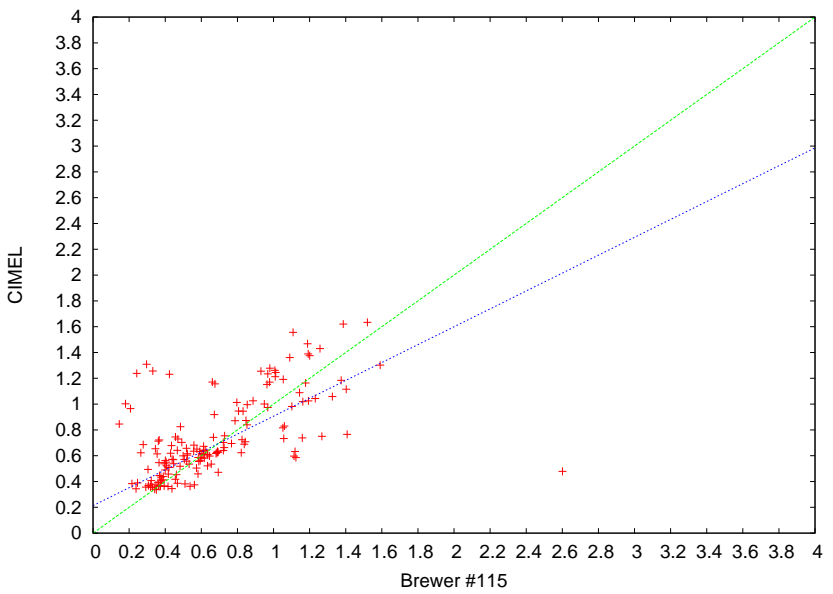

Fig. 6. 160 AODs from CIMEL at $340 \mathrm{~nm}$ shifted to $320 \mathrm{~nm}$ versus the AODs from Brewer \#115 at Hong Kong in China. The green and the blue lines represent the equation $f(x)=x$ and the absolute linear regression line for the data, respectively. The correlation coefficient, the slope and the intercept are $0.58,0.6932 \pm 0.1380$, $0.2132 \pm 0.0843$, respectively.

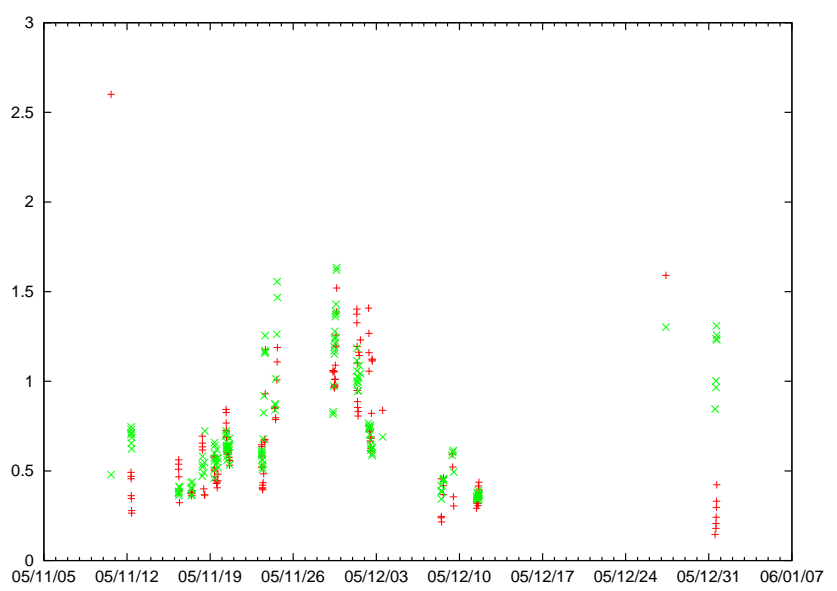

Fig. 7. Time series of the 160 AODs from CIMEL at $340 \mathrm{~nm}$ shifted to $320 \mathrm{~nm}$ (points in green) and the AODs from Brewer \#115 (points in red) at Hong Kong in China.

CIMEL sunphotometer are located at Yonsei University and Seoul National University, respectively, which is $16 \mathrm{~km}$ apart within Seoul in Korea. Yonsei university is located in downtown Seoul, while Seoul National University is at the Southern part, which is less polluted. They are operated since 2000 and 1999, respectively. The AOD at $440 \mathrm{~nm}$ shifted to $320 \mathrm{~nm}$ in using the Angström's coefficient $\alpha$ between 440 and $870 \mathrm{~nm}$ of the CIMEL and the AOD at $320 \mathrm{~nm}$ from the Brewer are compared.

In Seoul, 36 quasi simultaneous AODs at $320 \mathrm{~nm}$ from the Brewer \#148 are compared with AOD from the CIMEL at $440 \mathrm{~nm}$ on Figure 5. The correlation coefficient, the slope and the intercept are $0.72,1.0979 \pm 0.8844$ and

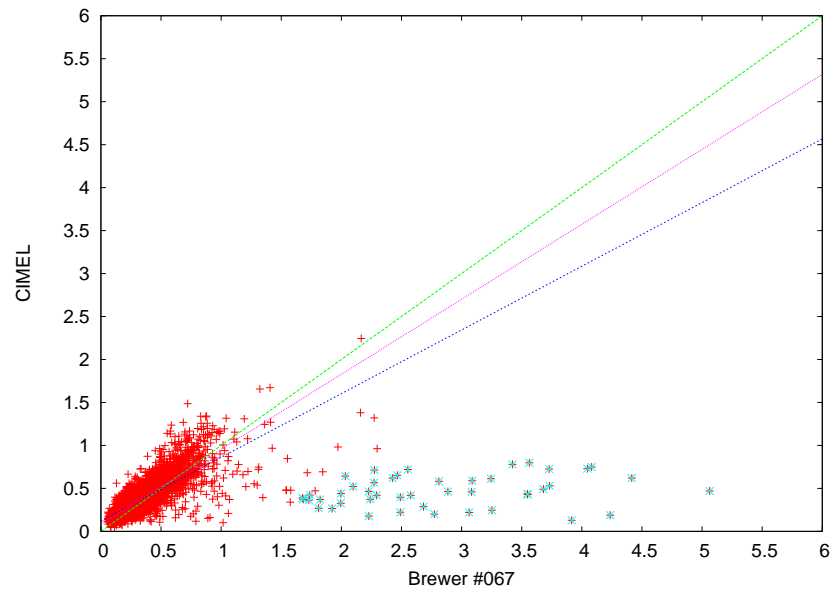

Fig. 8. 3385 AODs from CIMEL at $440 \mathrm{~nm}$ shifted to $320 \mathrm{~nm}$ versus the AODs from Brewer \#067 at Rome in Italy. The green and the blue lines represent the equation $f(x)=x$ and the absolute linear regression line for the data, respectively. The red line represents the absolute linear regression without the 45 outliers (red points with light blue cross). The correlation coefficient, the slope and the intercept are $0.50,0.7410 \pm 0.0638,0.1208 \pm 0.0178$, respectively: these parameters are clearly improved without considering the 45 outliers (red points with blue cross) $(0.78 ; 0.8724 \pm 0.0375$; $0.0835 \pm 0.0108)$.

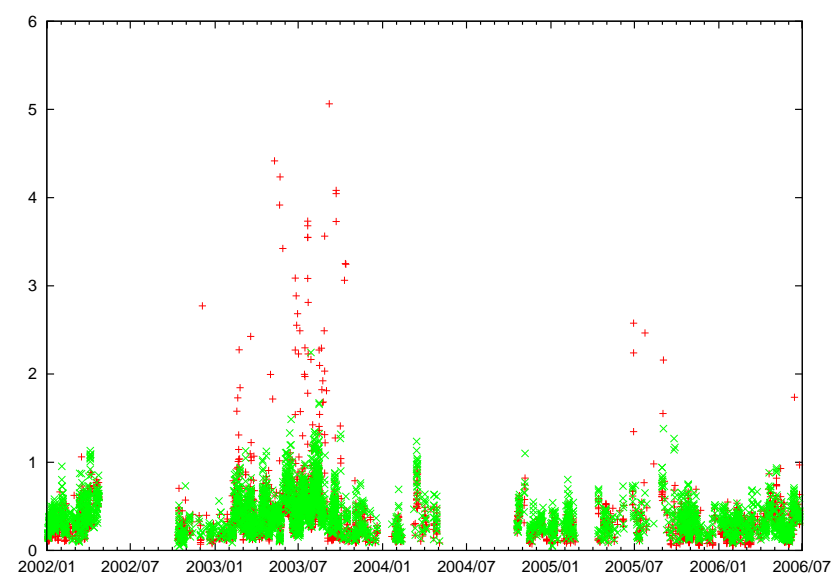

Fig. 9. Time series of the 3385 AODs from CIMEL at $440 \mathrm{~nm}$ shifted to $320 \mathrm{~nm}$ (in green) and the AODs from Brewer \#067 (in red) at Rome in Italy.

$0.1122 \pm 0.1820$, respectively. There is a good linear agreement between the two instruments but there is a noticeable bias.

As we only have 36 data, no final conclusion can be done on the accuracy of the AOD retrieved by the Brewer spectrophotometer in Seoul. 
Table 4. Comparisons between AODs from different Brewer and CIMEL sunphotometers: at Uccle in Belgium (\#016), at Toronto in Canada (\#008), at El Arenosillo in Spain (\#150), at Norrköping in Sweden (Cheymol et al, 2006), at Seoul in Korea (\#148), at Hong Kong in China (\#115) and at Rome in Italy (\#067). The slope (a) and the intercept (b) of the regression line are in parenthesis and the correlation coefficient (c) is outside the parenthesis. $\lambda_{\text {CIMEL }}$ is the wavelength used for the CIMEL, $\alpha$ is the alpha coefficient used for the CIMEL and N is the number of measurements compared.

\begin{tabular}{lcccc}
\hline Brewer & $\mathrm{c}, \mathrm{a}$ and $\mathrm{b}$ & $\lambda_{\text {CIMEL }}(\mathrm{nm})$ & $\alpha$ & $\mathrm{N}$ \\
\hline$\# 016$ & $0.96(1.0041 \pm 0.0183 ;-0.0744 \pm 0.0122)$ & 340 & $\alpha_{340--440}$ & 373 \\
$\# 008$ & $0.90(0.9943 \pm 0.0188 ; 0.0128 \pm 0.0060)$ & 340 & $\alpha_{340--440}$ & 550 \\
& $0.98(1.0000 \pm 0.0176 ; 0.0110 \pm 0.0056)$ & & & 548 \\
$\# 128$ & $0.97(1.0129 \pm 0.0097 ;-0.0153 \pm 0.0024)$ & 368 & $\alpha_{368--778}$ & 1522 \\
$\# 150$ & $0.82(0.9356 \pm 0.0149 ; 0.0001 \pm 0.0030)$ & 440 & $\alpha_{440--870}$ & 7386 \\
& $0.95(0.9467 \pm 0.0124 ;-0.0022 \pm 0.0027)$ & & & 7375 \\
$\# 148$ & $0.72(1.0979 \pm 0.8844 ; 0.1122 \pm 0.1820)$ & 440 & $\alpha_{440--870}$ & 36 \\
$\# 115$ & $0.58(0.6932 \pm 0.1380 ; 0.2132 \pm 0.0843)$ & 340 & $\alpha_{340--440}$ & 160 \\
$\# 067$ & $0.50(0.7410 \pm 0.0638 ; 0.1208 \pm 0.0178)$ & 440 & $\alpha_{440--870}$ & 3385 \\
& $0.78(0.8724 \pm 0.0375 ; 0.0835 \pm 0.0108)$ & & & 3340 \\
\hline
\end{tabular}

\subsubsection{Hong Kong in China}

The spectrophotometer MARK IV spectrophotometer \#115 is operated in the south eastern part of Hong Kong, which is a big city in China $\left(22^{\circ} 13^{\prime} \mathrm{N}, 114^{\circ} 15^{\prime} \mathrm{E}, 60 \mathrm{~m}\right.$ a.s.l.). It is located at a coastal site on top of a cliff facing South China Sea. This remote station encounters continental outflow in wintertime and clean maritime air in summertime. The CIMEL sunphotometer is operated in the centre of the city on the roof of the library of the Hong Kong Polytechnic University $\left(22^{\circ} 18^{\prime} \mathrm{N}, 114^{\circ} 10^{\prime} \mathrm{E}, 30 \mathrm{~m}\right.$ a.s.l. $)$, which means that it corresponds to urban aerosol conditions. The CIMEL is $12 \mathrm{~km}$ far from the Brewer. The AOD at $340 \mathrm{~nm}$ is taken into account for this study as it is the closest wavelength to the one of the Brewer at $320 \mathrm{~nm}$. The Brewer and the CIMEL are operated since 1995 and 2005, respectively.

160 AODs are compared from the Brewer spectrophotometer \#115 at $320 \mathrm{~nm}$ and the CIMEL sunphotometer at $340 \mathrm{~nm}$ shifted to $320 \mathrm{~nm}$ in using the Angström's coefficient $\alpha$ between 340 and $440 \mathrm{~nm}$ of the CIMEL on Fig. 6. The absolute linear relation between the instruments is poor (only 0.58 ), the slope and the intercept of the absolute regression line are $0.6932 \pm 0.1380$ and $0.2132 \pm 0.0843$, respectively. Fig. 7 shows the time series of the AOD from the CIMEL (points in green) and the Brewer (points in red) during the common period. At the end of 2005, the CIMEL measures larger AOD than the Brewer. The Brewer and the CIMEL are representing the urban and the rural atmospheric conditions respectively, which can explain part of the discrepancy. Nevertheless, further investigation need to be performed with a bigger dataset.

\subsubsection{Rome in Italy}

Rome $\left(41^{\circ} 54^{\prime} \mathrm{N}, 12^{\circ} 31^{\prime} \mathrm{E}\right)$ is a very populated city strongly influenced by anthropogenic activities (Meloni et al., 2000).
The CIMEL sunphotometer is operated since 2001 on the roof of the ISAC-CNR building in the southern suburbs of Rome about $15 \mathrm{~km}$ far from the city centre in a semirural site. The Brewer spectrophotometer \#067 is operated since 1992 in the centre of Rome westerly from the CIMEL. The AODs at wavelength $440 \mathrm{~nm}$ shifted to $320 \mathrm{~nm}$ in using the Angström's coefficient $\alpha$ between 440 and $870 \mathrm{~nm}$ of the CIMEL are compared to the AOD at $320 \mathrm{~nm}$ from the Brewer.

3385 quasi simultaneous data are compared on Fig. 8 and 9. If we consider all the data, there is a low linear correlation (0.50) between the AODs from the two instruments and it is probably due to the different location of the instruments: the Brewer spectrophotometer is strongly influenced by anthropogenic activities and the CIMEL is in a semi-rural site, which is less affected by pollution. Moreover, some of the AOD retrieved from the Brewer spectrophotometer are too high in 2003 (above two) to be realistic (see Fig. 9).

If we remove the 45 outliers (see Figure 8 the red point with blue crosses), the correlation coefficient rises to 0.78 with a slope and an intercept equal to $0.8724 \pm 0.0375$ and $0.0835 \pm 0.0108$, respectively. These outliers have occurred due to technical problem. Further investigation would be nevertheless useful to confirm this assumption. For more details on selection of outliers, see Sect. 4.

\section{Selection of outliers}

In this article, an outlier or a set of outliers should be understood as outliers to an expected linear dependence between direct aerosol measurements from CIMEL sunphotometer and ozone derived aerosol measurements from Brewer spectrophotometer. Recent advances in linear regression (Rousseeuw, 1984) allow to have a more robust estimation of the variance, $\sigma$, of the residuals $\left(r_{i}^{2}=y_{i}-a x_{i}-b\right)$ than 
with the usual least mean square or even the least mean absolute methods. The median of the residuals is then minimized by the equation:

$\sigma=1.483 \sqrt{\operatorname{median}_{1 \ldots n} r_{i}^{2}}$

If the absolute value of a residual divided by the variance is higher than a limit $\lambda$, this data value could be considered as an outlier. $\lambda$ is chosen to detect the outliers determined by visual inspection in the two easier cases (Fig. 3 Toronto and Fig. 4 El Arenosillo). In Fig. 8, it is more difficult to determine the outliers. The outliers for Rome are detected in fixing the value of $\lambda$ to 9.40 . If additional values are considered as outliers by lowering $\lambda$, the regression parameters do not change significantly.

\section{Conclusions}

Table 4 summarises all the intercomparisons. The following conclusions can be made:

If the instruments are co-located and measure at the same wavelength the correlation coefficient is very high, the slope of the regression line is about 1 and its intercept is virtually equal to 0.

In El Arenosillo, the 11 outliers are not yet explained. Without considering these outliers, the AOD measured by the Brewer and the CIMEL are very close.

In Norrköping in Sweden, in applying the Angström's law, the intercomparison between both instruments is improved compared to the comparison between AOD at $368 \mathrm{~nm}$ and $320 \mathrm{~nm}$ (Cheymol et al., 2006): the correlation coefficients are quite the same and the slope is closer to 1 (without the shifting, the slope is equal to 0.85 ).

For two instruments operated at different sites like in Rome or in Hong Kong, the correlation is lower. It confirms the previous conclusion in Cheymol et al., 2006: AOD validation needs to have co-located instruments. The difference between AOD from the two instruments have different cause: the poor co-location (Hong Kong and Rome) and probably technical problems (Rome). Moreover, some error can be induced by an error on the neutral density filter values [Cheymol et al., 2006].

This study is needed to go further to determine the main source of the discrepancy between AOD from Brewer and CIMEL at El Arenosillo (due to the 11 outliers), Hong Kong and Rome.

Acknowledgements. This study was supported by the Belgian Science Policy (Contract action 1: "Aerosol Optical Depth derived from ground based spectral observations of solar radiation"). We thank the PI investigators (Christian Hermans, Belgian Institute for Space Aeronomy, Belgium; Brent Holben, for Toronto in Canada; Janet Elizabeth Nichol for Hong Kong in China; Soon-Chang Yoon for Seoul in Korea; Gian Paolo Gobbi for Rome in Italy and Victoria E. Cachorro Revilla for El Arenosillo in Spain) and their staff for establishing and maintaining the AERONET sites used in this study. We thank also Alessandro Ipe (from the GERB team) for his computer support and his review. We also thank Jose Manuel Vilaplana and Weine Josefsson, who provided us the Brewer data at El Arenosillo and Norrköping respectively and the anonymous reviewers for their comments. The work for J. Kim was supported by the Eco-technopia 21 project under grant $121-071-055$ by the Korea Ministry of Environment.

Edited by: T. Bond

\section{References}

Angström, A.: The parameters of atmospheric turbidity, Tellus, 16, 64-75, 1964.

Arola, A. and Koskela, T.: On the sources of bias in aerosol optical depth retrieval in the UV range, J. Geophys. Res., 109, D08209, doi:10.1029/2003JD004375, 2004.

Bais, A., Kazantzidis, A., Kazadzis, S., Balis, D. S., Zerefos, C. S., and Meleti, C.: Deriving an effective aerosol single scattering albedo from spectral surface UV irradiance measurements, Atmos. Environ., 39, 1013-1102, 2004.

Brussels Institute for Management of the Environment (BIM): La qualité de l'air en région de Bruxelles capitale: les particules en suspension en 2004, technical report, online: www.ibgebim.be/ francais/contenu/content.asp?ref=1888, 2004.

Carvalho, F. and Henriques, D.: Use of Brewer ozone spectrophotometer for aerosol optical depth measurements on ultraviolet region, Adv. Space Res., 25, 997-1006, 2000.

Cede, A., Kazadzis, S., Kowalewski, M., Bais, A., Kouremeti, N., Blumthaler, M., and Herman, J.: Correction of direct irradiance measurements of Brewer spectrophotometers due to the effect of internal polarization, Geophys. Res. Lett., 33, L02806, doi:10.1029/2005GL024860, 2006

Chou, M.-D., Lin, P.-H., Ma, P.-L., and Lin, H.-J.: Effects of aerosols on the surface solar radiation in a tropical urban area, $\mathrm{J}$. Geophys. Res., 111, D15207, doi:10.1029/2005JD006910, 2006.

Cheymol, A., De Backer, H., Josefsson, W., and Stuebi, R.: Comparison and validation of the aerosol optical depth obtained with the Langley plot method in the UV-B from Brewer Ozone Spectrophotometer measurements, J. Geophys. Res., 111, D16202, doi: 10.1029/2006JD007131, 2006.

Cheymol, A. and De Backer, H.: Retrieval of aerosol optical depth in the UV-B at Uccle from Brewer ozone measurements over a long time period 1984-2002, J. Geophys. Res., 108,(D24), doi:10.1029/2003JD003758, 2003.

de La Casinière A., V. Cachorro, I. Smolskaia, J. Lenoble, M. Sorribas, M. Houet, O. Massot, M. Antón, and J.M. Vilaplana, (2005), Comparative measurements of total ozone amount and aerosol optical depth during a campaign at El Arenosillo, Huelva, Spain, Annals Geophysicae, 23, 3399-3406.

Efron, B. and Tibshirani, R.: Bootstrap Methods for Standard Errors, Confidence Intervals and Other Measures of Statistical Accuracy, Stat. Sci., 1(1), 54-77, 1986.

Fioletov V. E., Kerr, J. B., McElroy, C. T., Wardle, D. I., Savastiouk, V., and Grajnar, T. S.: The Brewer reference triad, Geophys. Res. Lett., 32, L20805, doi:10.1029/2005GL024244, 2005.

Gröbner, J. and Meleti, C.: Aerosol optical depth in the UVB and visible wavelength from Brewer spectrophotometer direct irradi- 
ance measurements: 1991-2002, J. Geophys. Res., 109, D09202, doi:10.1029/2003JD004409, 2004.

Gröbner J., Vergaz, R., Cachorro, V. E., Henriques, D. V., Lamb, K., Redondas, A., Vilaplana, J. M., and Rembges, D.: Intercomparison of aerosol optical depth measurements in the UVB using Brewer spectrophotometers and a Li-Cor spectrophotometer, Geophys. Res. Lett., 28(9), 1691-1694, 2001.

Holben, B. N., Eck, T. F., Slutsker, I., Tanr, D., Buis, J. P., Setzer, A., Vermote, E., Kaufman, J. A., Nakajima, T., lavenu, F., Jankoowiak, I., and Smirnov, A.: AERONET- A federated Instrument Network and Data Archive for Aerosol Characterisation, Rem. Sens.Environ., 66, 1-16, 1998.

Intergovernmental Panel on Climate Change (IPCC): Climate change: The scientific basis, edited by: Houghton, J. T., Ding, Y., Griggs, D. J., Noguer, M., van der Linden, P. J., Xiaosu, D., Maskell, K., and Johnson, C. A., Cambridge Univ. Press, 896 pp., 2001.

Jaroslawski J. P. and Krzyscin, J. W.: Importance of aerosol variations for surface UV-B level: Analysis of ground-based data taken at Belsk, Poland, 1992-2004, J. Geophys. Res., 110, D16201, doi:10.1029/2005JD005951, 2005.

Kazadzis S., Bais, A., Kouremeti, N., Gerasopoulos, E., Garane, K., Blumthaler, M., Schallhart, B., and Cede, A.: Direct spectral measurements with a Brewer spectroradiometer: absolute calibration and aerosol optical depth retrieval, Appl. Opt., 44(9), 1691-1690, 2005.

Mallet, M., Van Dingenen, R., Roger, J. C., Despiau, S., and Cachier, H.: In situ airborne measurements of aerosol optical properties during photochemical pollution events, J. Geophys. Res., 110, D03205, doi:10.1029/2004JD005139, 2005.

Marenco, F., di Sarra, A., and De Luisi, J.: Methodology for determining aerosol optical depth from Brewer 300-320-nm ozone measurements, Appl. Opt., 41(9), 1805-1814, 2002.

Marenco F., Santacesaria, V., Bais, A. F., Balis, D., di Sarra, A., Papayannis, A., and Zerefos, C.: Optical properties of tropospheric aerosols determined by lidar and spectrophotometric measurements (photochemical activity and solar ultraviolet radiation campaign), Appl. Opt., 36(27), 6875-6886, 1997.
Meloni, D., Casale, G. R., Siani, A. M., Palmieri, S., Cappelani, F.: Solar UV dose patterns in Italy, Photochem. Photobiol., 71(6), 681-690, 2000.

Pfeifer M. T., Koepke, P., and Reuder, J.: Effects of altitude and aerosol on UV radiation. J. Geophys. Res., 111, D10S08, doi:10.1029/2005JD006180, 2006.

Roberts D. L. and Jones, A.: Climate sensitivity to black carbon aerosol from fossil fuel combustion, J. Geophys. Res., 109, D16202, doi:10.1029/2004JD004676, 2004.

Rousseeuw P. J.: Least Median of Squares Regression, J. Am. Stat. Assoc., 79(388), 871-880, 1984.

See, S. W., Balasubramanian, R., and Wang, W.: A study of the physical, chemical, and optical properties of ambient aerosol particles in Southeast Asia during hazy and non hazy days, J. Geophys. Res., 111, D01203, doi:10.1029/2005JD006444, 2006.

Savastiouk, V. and McElroy, C. T.: Brewer spectrophotometer Total Ozone Measurements Made during the 1998 Middle Atmosphere Nitrogen Trend Assessment (MANTRA) Campaign, Atmos.Ocean, 43(4), 315-324, 2005.

SCI TEC: Brewer ozone spectrophotometer, Acceptance manual, Document number AM-BA-C05-Rev C, SCI TEC Instruments, 1988.

Sellitto, P., di Sarra, A., and Siani, A. M.: An improved algorithm for the determination of aerosol optical depth in the ultraviolet spectral range from Brewer spectrophotometer observations. J. Optics: pure and applied optics, 8, 849-855, 2006.

Toledano, C.: Climatología de los aerosoles mediante la caracterizacíonde propiedades ópticas y masas de aire en la estación 'El Arenosillo' de la red AERONET, Ph. Thesis, Universidad de Valladolid, Spain, 237 pp., 2005.

Wild, M., Ohmura, A., and Makowski, K.: Impact of global dimming and brightening on global warming, Geophys. Res. Lett., 34, L04702, doi:10.1029/2006GL028031, 2007.

Wild, M., Gilgen, H., Roesch, A., Ohmura, A., Long, C. N., Dutton, E. G., Forgan, B., Kallis, A., Russak, V., and Tsvetkov, A.: From dimming to brightening: decadal changes in solar radiation at Earth's surface, Science, 308, 847-850, 2005. 